in the sun's rather strong magnetic field) and, as it would be at slower velocity, there would be a solar electric charge. Yet, as I understand, G. E. Hale could not find any trace of Stark effect of resulting solar electric field : which would be adequately explained if the electric charge, being of course a surface sheet, lies outside the layer which emits the light. The penetration of the cosmic radiation, if it carry a. charge, or part of it, into the earth has been in like manner assigned as a cause maintaining the earth's electric charge ${ }^{6}$ : by the usual estimate it would have to replenish the static charge of the earth every ten minutes. The spatial density of compensating charge falling back into the sun would be considerable if it fell slowly : but there is scarcely ground for connecting the fixed spectral lines of some double stars with an atmosphere of that kind. This principle of emission in one mode and compensating absorption in another, is far-reaching : thus it is the foundation of the Einstein theory of radiation by projected and absorbed 'photons'.

The characteristic feature of the modern spectral theory, expressing itself in sporadic transitions between energy levels, is that, while it aims at inclusion of the Hamiltonian dynamical analysis, each line has its own configuration of the source, without any overtones such as were a necessary part of a vibrational theory. The equation of HamiltonJacobi and the related one of Schrödinger would belong not to an atom but to a cosmos, thus coming into line towards the various universal modes of statistics. In asymptotic limit ${ }^{2}(\lambda$ large) the two schemes, Hamilton's (generalised) rays and Schrödinger's potential, come into agreement.

1 NATURE, 132, 340, Sept. 2, 1933.

2 Proc. Roy. Soc., 1928.

${ }^{3}$ cf. Phil. Mag., Jan. 1884; "Math. and Phys. Papers," vol. 1, p. 28 .

- Terrestrial Magnetism, 1931-33.

5 Proc. Phys. Soc., Feb. When this was written I had not seen their records for short waves, and their cyclicity in the magnetic fleld, which is not very far from vertical, in Phil. Mag. for July. Clearly there is much to be learned here.

- cf. Kolhörster, H., Nature, 132, 407, Sept. 9, 1933.

" cf. Dirac's "Quantum Mechanics," p. 121; G. D. Birkhoff, Proc. Nat. Acad., March 1933, p. 339 : also Ievi-Cività, Bull. Amer. Math. Soc., Aug. 1933. An early attempt toward such correlation is in the writer's "Papers", vol. 2 (1928), p. 809.

\title{
Anniversary of the Asiatic Society of Bengal
}

$\mathrm{O}^{\mathrm{N}}$ January 15 the Asiatic Society of Bengal celebrated the 150th anniversary of its foundation by an afternoon conversazione in the Indian Museum, and a banquet in the evening followed by a special anniversary meeting. The conversazione was attended by the Mayor of Calcutta and about five hundred of the leading citizens of Calcutta. It took the form of a garden party on the lawn of the Museum and special and interesting collections of exhibits, consisting of paintings lent by the Academy of Fine Arts, copies of old documents from the Imperial Records Department, mostly of the eighteenth century and some concerning the Asiatic Society, paintings of plants from the Botanical Survey, Javanese and Siamese sculptures lent by Dr. S. K. Chatterji, chemical and physical demonstrations arranged by the University College of Science and Technology, prehistoric and tenth century finds from the Archæological Survey, fossils, crystals and economic products from the Geological Survey, birds of Bengal lent by Dr. S. C. Law, demonstrations of the prevention and treatment of disease arranged by the School of Tropical Medicine and Hygiene, medals and coins by His Majesty's Mint, Kaffir attire, fish, Crustacea and insects from the Zoological Survey.

The banquet was honoured by the presence of $\mathrm{His}$ Excellency Sir John Anderson, Governor of Bengal, who is the patron of the Society, and took place in its one hundred and twenty-six year old hall, surrounded by portraits and busts of former members who have made history in Bengal. Ninety-three members and guests were present, including the consular representatives of France, Germany, Holland, Sweden and the United States of America, the Archbishop of Calcutta, the Hon. Sir M. N. Roy Chowdhury, Sir David Ezra, the Hon. Nawab K. G. M. Faroqui, Sir C. C. Ghose, the Hon. Sir A. K. Ghuznavi, Lord Sinha, the Hon. Sir B. P. Singh Roy, and Sir Jadu Nath Sircar. The toast of the guests was proposed by the president of the Society, Dr. L. L. Fermor, to which M. J. Delacour, of the National Museum of Paris replied, and also proposed the Asiatic Society, but speeches were brief, in view of the meeting afterwards.
At the special anniversary meeting, His Excellency the Governor took the chair and the president delivered his anniversary address, outlining the history of the Society, and naming the distinguished contributors to its publications, more especially in the last half century. He pointed out that many of the specialist departments and institutions founded in India originated from the Asiatic Society, in particular the Indian Science Congress, and mentioned the proposals which had been made for the formation of an Indian Academy of Sciences to affect co-ordination between these various interests in the sphere of science.

Following the president's address, congratulatory messages were read from His Excellency the Viceroy, the Mayor of Calcutta, the League of Nations, Prof. C. Rockwell Lanman, Sir George Grierson and Sir Thomas Holland (honorary fellows). Seven addresses were read, from the British Museum, the Linnean Society, the Zoological Society of London, the Batavian Society of Arts and Sciences, the Indian Institute, Oxford, the Schopenhauer Society, Frankfort, and the Prussian Academy of Sciences Congratulations were presented by 26 delegates from 58 learned institutions, and in all 19 countries were represented-Australia, Austria, Belgium, Ceylon, Canada, France, Federated Malay States, Germany, Great Britain, Hungary, Italy, Japan, Netheriands, Spain, Sweden. Switzerland, Tasmania, United States and India.

Twelve honorary anniversary members were elected-six in letters and six in science: Prof. Arthur Christensen of Denmark, Prof. Taha Husain of Cairo, Sir John Marshall, lately Director-General of Archæology in India, H.R.H. Prince Damrong Rajahubhab of Siam, Dr. Rabindranath Tagore, Dr. J. Van Kan, law member of the Council of the Viceroy of the Dutch East Indies, Sir Sidney Burrard, lately Surveyor-General in India, Prof. Albert Einstein, Sir Sven Hedin, Prof. Alfred Lacroix, Dr. Henry Fairfield Osborn and Lord Rutherford.

In his speech, His Excellency the Governor stressed the vigour of the Society in spite of its age, its permanence since the days of the French Revolu- 
tion, and the esteem in which it is held abroad, as manifested by the spontaneous tributes received from all over the world. He directed attention to the traditional connexion of the ruling princes of India with the Society, and hoped that this tradition might be widened, to the benefit of scholarship, by the inclusion in the Society's list of members of the name of every substantial ruler in the country.

His Excellency paid special tribute to three members of the Society, Sir Rajendranath Mookerjee, Mr. John Van Manen (general secretary) and Dr. S. L. Hora (honorary secretary of the Celebration Committee).

\section{Research in the British Post Office}

W

HEN the State purchased the telegraphs in Great Britain in 1869, the number of electrical workers in the whole country could almost be counted on the fingers. To-day the engineer-in-chief of the Post Office controls a staff of about 30,000 and maintains plant of a value of 130 million pounds. Starting from the needle instruments, skilled Post Office experimentalists developed the Wheatstone transmitter and receiver ; instruments capable of operating up to 300 words per minute.

Capt. B. S. Cohen, the engineer of the Post Office Research Station at Dollis Hill, in a paper read to the Institution of Electrical Engineers on February 1, said that these instruments still stand unsurpassed to-day in their design, workmanship and performance. It was not until 1912 that a research section was established. During the War period, the thermionic valve was perfected and at one stroke opened a boundless vista of possibilities in the way of universal telephone communication. The paramount necessity was to obtain the closest co-ordination between the research and the operating organisations. Without full access for research purposes to the working telegraph and telephone plant, the work of the research engineers would have been immensely increased. The Research Station at Dollis Hill was started in 1921 by using ex-army huts, and the permanent buildings were completed last year. Much excellent work has been done at this station which could not have been done elsewhere.

To the research workers at Dollis Hill the increase in the volume and weight of road traffic brought with it a new problem. There are apparently under the streets an ever-increasing number of cracked gas mains. Modern road surfaces make it difficult for this gas to escape into the open and so it sometimes accumulates in Post Office cable ducts and manholes, involving a serious hazard. The research engineers have developed a simple form of gas detector for general issue to Post Office workmen. The detector operates in a way somewhat similar to a photographic exposure meter. It utilises a filter paper moistened with a few drops of palladium chloride solution and will indicate the presence of 0.05 per cent of carbon monoxide, the dangerous constituent of coal gas.

The capital value of automatic switching apparatus installed in exchanges is now very large, and great precautions against corrosion have to be taken. Sir Robert Hadfield has said that the corrosion of iron and steel alone costs the world 700 million pounds per annum. Experiment shows that the life of galvanised iron stay wire is proportional to the thickness of the galvanising. In some parts of south
Lancashire, the normal life of a stay wire is little more than two years. It is now possible to estimate the life of any particular grade of wire in a given area.

In long telephone lines the 'echo' used to be very troublesome but the engineers have invented, using valves only, a very efficient echo-suppressor. A nonreflecting room at the Station has linings of cottonwool one foot thick. This room has a totally silent background of noise. It is especially useful for listening tests where the threshold of hearing has to be found.

\section{University and Educational Intelligence}

Cambridge.-At St. John's College, one Strathcona research studentship of the annual value of $£ 150$ and two Strathcona exhibitions of the annual value of $£ 40$ are offered for competition amongst research students who are graduates of any university other than Cambridge. The election of a candidate not yet a member of the College is subject to his being accepted by the University as a research student proceeding to the $\mathrm{Ph} . \mathrm{D}$. degree and to his commencing residence in October 1934. Candidates must make application to the Senior Tutor, St. John's College, not later than July 1.

London.--Dr. G. P. Wright has been appointed as from March 1 Sir William Dunn professor of pathology tenable at Guy's Hospital Medical School. Since 1931, Dr. Wright has been assistant lecturer in morbid anatomy and curator of the Museum at University College Hospital Medical School and also pathologist to the Hospital.

It is expected that the new British Postgraduate Medical School at Hammersmith will be opened to students in October next. It has been given recognition as a School of the University for a period of two years, as a temporary measure.

OxFond.-In presenting Miss Ethel Bellamy for the honorary degree of M.A. on January 30, the Public Orator, Mr. C. Bailey, took occasion to remind Convocation of the distinguished services rendered by that lady and other members of her family in the cause of astronomy, and particularly in the important part taken by the Oxford Observatory in the photographic survey of the heavens. In consideration of the recent help accorded to the Vatican Observatory towards the completion of that work, the Pope has bestowed on Miss Bellamy a decoration of silver.

ST. Andrews.-The Court has agreed to institute a lectureship in bacteriology in the University and has appointed Mr. James F. Murray, who has hitherto been assistant to the professor of bacteriology, to the lectureship as from February 1 ; Mr. A. B. Stewart has been appointed to succeed Mr. Murray as assistant in the Department.

THE booklet on the new buildings of the University of London, edited by T. Ll. Humberstone and published by the Dryden Press (see Nature, June 24,1933 , p. 903 ) has been withdrawn from publication and replaced by a similar book containing also a report of the stone-laying ceremony by the King on June 26. This is published by Mr. William Rice, 3 Ludgate Broadway, E.C.4, at $2 s .6 d$. 